\title{
A novel $R$-stereoselective amidase from Pseudomonas sp. MCI3434 acting on piperazine-2-tert-butylcarboxamide
}

\author{
Hidenobu Komeda ${ }^{1}$, Hiroyuki Harada ${ }^{1}$, Shingo Washika', Takeshi Sakamoto ${ }^{2}$, Makoto Ueda ${ }^{2}$ \\ and Yasuhisa Asano ${ }^{1}$ \\ ${ }^{1}$ Biotechnology Research Center, Toyama Prefectural University, Kurokawa, Kosugi, Toyama, Japan; ${ }^{2}$ Mitsubishi Chemical Group \\ Science and Technology Research Center, Inc., Aoba-ku, Yokohama, Kanagawa, Japan
}

A novel amidase acting on $(R, S)$-piperazine-2-tert-butylcarboxamide was purified from Pseudomonas sp. MCI3434 and characterized. The enzyme acted $R$-stereoselectively on $(R, S)$-piperazine-2-tert-butylcarboxamide to yield $(R)$ piperazine-2-carboxylic acid, and was tentatively named $\mathrm{R}$-amidase. The $\mathrm{N}$-terminal amino acid sequence of the enzyme showed high sequence identity with that deduced from a gene named PA3598 encoding a hypothetical hydrolase in Pseudomonas aeruginosa PAO1. The gene encoding R-amidase was cloned from the genomic DNA of Pseudomonas sp. MCI3434 and sequenced. Analysis of $1332 \mathrm{bp}$ of the genomic DNA revealed the presence of one open reading frame $(\operatorname{ram} A)$ which encodes the R-amidase. This enzyme, RamA, is composed of 274 amino acid residues (molecular mass, $30128 \mathrm{Da}$ ), and the deduced amino acid sequence exhibits homology to a carbon-nitrogen hydrolase protein (PP3846) from Pseudomonas putida strain KT2440 (72.6\% identity) and PA3598 protein from $P$. aeruginosa strain PAO1 (65.6\% identity) and may be classified into a new subfamily in the carbon-nitrogen hydrolase family consisting of aliphatic amidase, $\beta$-ureidopropionase, carbamylase, nitrilase, and so on. The amount of R-amidase in the supernatant of the sonicated cell-free extract of an
Escherichia coli transformant overexpressing the $\operatorname{ram} A$ gene was about 30000 times higher than that of Pseudomonas sp. MCI3434. The intact cells of the $E$. coli transformant could be used for the $R$-stereoselective hydrolysis of racemic piperazine-2-tert-butylcarboxamide. The recombinant enzyme was purified to electrophoretic homogeneity from cell-free extract of the E. coli transformant overexpressing the ramA gene. On gel-filtration chromatography, the enzyme appeared to be a monomer. It had maximal activity at $45^{\circ} \mathrm{C}$ and $\mathrm{pH} 8.0$, and was completely inactivated in the presence of $p$-chloromercuribenzoate, $N$-ethylmaleimide, $\mathrm{Mn}^{2+}$, $\mathrm{Co}^{2+}, \mathrm{Ni}^{2+}, \mathrm{Cu}^{2+}, \mathrm{Zn}^{2+}, \mathrm{Ag}^{+}, \mathrm{Cd}^{2+}, \mathrm{Hg}^{2+}$ or $\mathrm{Pb}^{2+}$. RamA had hydrolyzing activity toward the carboxamide compounds, in which amino or imino group is connected to $\beta$ - or $\gamma$-carbon, such as $\beta$-alaninamide, $(R)$-piperazine-2carboxamide $(R)$-piperidine-3-carboxamide, D-glutaminamide and (R)-piperazine-2-tert-butylcarboxamide. The enzyme, however, did not act on the other amide substrates for the aliphatic amidase despite its sequence similarity to RamA.

Keywords: amidase; hydrolysis; piperazine-2-tert-butylcarboxamide; Pseudomonas sp.; stereoselectivity.
Amidases (acylamide amidohydrolases, EC 3.5.1.4), which are hydrolases acting on carboxyl amide bonds to liberate carboxylic acids and ammonia, have received much attention in applied microbiological field. Amidases from various microorganisms have been characterized to date. Aliphatic (wide-spectrum) amidases acting on aliphatic amides with short acyl chains were found in Pseudomonas aeruginosa [1], Brevibacterium sp. R312 [2], Helicobacter pylori [3] and Bacillus stearothermophilus BR388 [4]. Pyrazinamidase/ nicotinamidase confers susceptibility to the antituberculous

Correspondence to Y. Asano, Biotechnology Research Center, Toyama Prefectural University, 5180 Kurokawa, Kosugi,

Toyama 939-0398, Japan.

Fax: + 8176656 2498, Tel.: + 81766567500 ,

E-mail: asano@pu-toyama.ac.jp

Abbreviations: NBD-Cl, 4-chloro-7-nitro-2,1,3-benzoxadiazole;

ORF, open reading frame.

Enzymes: acylamide amidohydrolases (EC 3.5.1.4).

(Received 30 January 2004, revised 28 February 2004,

accepted 3 March 2004) drug pyrazinamide in Mycobacterium [5]. Many different kinds of microbial amidases with stereoselectivity have also been reported and some of them have been applied for the production of optically active compounds from the corresponding racemic amides [6-8]. $S$-enantiomer-selective amidases in Brevibacterium sp. R312 [9], Pseudomonas chlororaphis B23 [10] and Rhodococcus rhodochrous J1 [11] are involved in nitrile metabolism with a genetically linked nitrile hydratase. $S$ - and $R$-enantiomer-selective amidase, which appeared not to be related to nitrile metabolism, were also found in Agrobacterium tumefaciens d3 [12] and Comamonas acidovorans KPO-2771-4 [13], respectively. $S$-Stereoselective amino acid amidases from Pseudomonas putida ATCC 12633 [14], Ochrobactrum anthropi NCIMB 40321 [15], and Mycobacterium neoaurum ATCC 25795 [16] can be used for the enzymatic production of $(S)$-amino acids from the corresponding racemic amino acid amides. $R$-Stereoselective amino acid amidases from $O$. anthropi SV3 [17], Arthrobacter sp. NJ-26 [18] and Brevibacillus borstelensis BCS-1 [19] were also used for the production of $(R)$-amino acids from racemic amino acid amides. The genes coding for the above amidases have been isolated and 
their primary structures revealed, except for the $S$-stereoselective amino acid amidases of the three microorganisms and the $R$-stereoselective amino acid amidase from Arthrobacter sp. NJ-26. Although these amidases show a wide variety of substrate specificities, there is no report on the hydrolysis of amides containing a bulky substituent at the amide nitrogen, such as tert-butylcarboxamide. This inability to hydrolyze the bulky amides hindered the wide use of amidases for the production of complex compounds.

Enantiomerically pure piperazine-2-carboxylic acid and its tert-butylcarboxamide derivative are important chiral building blocks for some pharmacologically active compounds such as $N$-methyl-D-aspartate antagonist for glutamate receptor [20], cardioprotective nucleoside transport blocker [21], and HIV protease inhibitor [22]. (S)-Piperazine-2carboxylic acid has been prepared by kinetic resolution of racemic 4-(tert-butoxycarbonyl)piperazine-2-carboxamide with leucine aminopeptidase [21] or racemic piperazine-2carboxamide with Klebsiella terrigena DSM9174 cells [23]. There is no report on the kinetic resolution of $(R, S)$-piperazine-2-tert-butylcarboxamide.

In this study, we screened for microorganisms that can hydrolyze piperazine-2-tert-butylcarboxamide and found the hydrolytic (amidase) activity in Pseudomonas sp. MCI3434. The amidase purified from cells of the strain hydrolyzed $R$-stereoselectively piperazine-2-tert-butylcarboxamide to form $(R)$-piperazine-2-carboxylic acid (Fig. 1), and was tentatively named R-amidase. The gene coding for the R-amidase was isolated, sequenced and expressed in an Escherichia coli host. The recombinant protein was purified and characterized, and found to be a novel amidase with a unique substrate specificity.

\section{Materials and methods}

\section{Bacterial strains, plasmids and culture conditions}

Pseudomonas sp. MCI3434 (TPU7190 of Toyama Prefectural University) was selected as a microorganism capable of degrading $(R, S)$-piperzine-2-tert-butylcarboxamide and used as the source of enzyme and chromosomal DNA. E. coli JM109 (recA1, endA1, gyrA96, thi, hsdR17, supE44, relA1, $\Delta \quad($ lac-proAB $) / \mathrm{F}^{\prime} \quad\left[\right.$ traD36, proAB ${ }^{+}, \quad$ lacl $1^{\mathrm{q}}$, lac $Z \Delta \mathrm{M} 15])$ was used as a host for the recombinant plasmids. Plasmids pBluescriptII SK(-) (Toyobo, Osaka, Japan) and pUC19 (Takara Shuzo, Kyoto, Japan) were used as cloning vectors. Pseudomonas sp. MCI3434 was grown in medium I containing $10 \mathrm{~g}$ Bonito extract (Wako Pure Chemical Industries, Ltd, Osaka, Japan), $10 \mathrm{~g}$ disodium DL-malate $n$-hydrate, $3 \mathrm{~g} \mathrm{~K}_{2} \mathrm{HPO}_{4}$ and $1 \mathrm{~g} \mathrm{KH}_{2} \mathrm{PO}_{4}$ in $1 \mathrm{~L}$ distilled water, $\mathrm{pH}$ 7.0. Recombinant $E$. coli JM109 was cultured in Luria-Bertani medium [24] containing ampicillin $\left(80 \mu \mathrm{g} \cdot \mathrm{ml}^{-1}\right)$. To induce expression of the gene

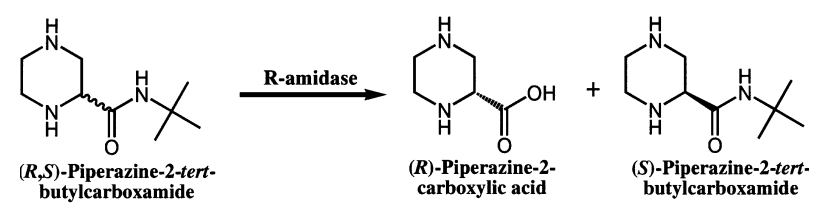

Fig. 1. Stereoselective hydrolysis of racemic piperazine-2-tert-butylcarboxamide by the R-amidase (RamA) from Pseudomonas sp. MCI3434. under the control of the lac promoter, isopropyl thio- $\beta$ D-galactoside was added to a final concentration of $0.5 \mathrm{~mm}$.

\section{Purification of the R-amidase from Pseudomonas sp. MCI3434}

Pseudomonas sp. MCI3434 was subcultured at $30{ }^{\circ} \mathrm{C}$ for $16 \mathrm{~h}$ in a test tube containing $5 \mathrm{~mL}$ of medium I. The subculture $(5 \mathrm{~mL})$ was then inoculated into a $2 \mathrm{~L}$ Erlenmeyer flask containing $500 \mathrm{~mL}$ of medium I. After an $8 \mathrm{~h}$ incubation at $25^{\circ} \mathrm{C}$ with reciprocal shaking, the cells were harvested by centrifugation at $10000 \mathrm{~g}$ for 20 min at $4{ }^{\circ} \mathrm{C}$ and washed with $0.9 \%(\mathrm{w} / \mathrm{v}) \mathrm{NaCl}$. All the purification procedures were performed at a temperature lower than $4{ }^{\circ} \mathrm{C}$. The buffer used was potassium phosphate (pH 7.0) containing $0.1 \mathrm{~mm}$ dithiothreitol and $5 \mathrm{~mm}$ 2-mercaptoethanol. Washed cells (125 g, wet weight) from $25 \mathrm{~L}$ of culture were suspended in $0.1 \mathrm{M}$ buffer and disrupted by sonication for $10 \mathrm{~min}(19 \mathrm{kHz}$; Insonator model 201M; Kubota, Tokyo, Japan). The sonicate was centrifuged at $15000 \mathrm{~g}$ for $20 \mathrm{~min}$ at $4{ }^{\circ} \mathrm{C}$, and the resulting supernatant was used as the cell-free extract. The cell-free extract was dialyzed for $24 \mathrm{~h}$ against three changes of $10 \mathrm{~mm}$ buffer. The dialyzed enzyme solution was then applied to a column $(6 \times 15 \mathrm{~cm})$ of DEAE-Toyopearl $650 \mathrm{M}$ (Tosoh Corp.) previously equilibrated with $10 \mathrm{~mm}$ buffer. After the column had been washed with $2 \mathrm{~L}$ of $10 \mathrm{~mm}$ buffer, the enzyme was eluted with a $10 \mathrm{~mm}$ buffer containing $0.1 \mathrm{M} \mathrm{NaCl}$. The protein content of the eluates from the column chromatography was monitored by measuring absorbance at $280 \mathrm{~nm}$. The active fractions were combined and then brought to $30 \%$ ammonium sulfate saturation and applied to a column $(3 \times 12 \mathrm{~cm})$ of butyl-Toyopearl $650 \mathrm{M}$ (Tosoh Corp.) previously equilibrated with $10 \mathrm{~mm}$ buffer $30 \%$ saturated with ammonium sulfate. The column was washed with $500 \mathrm{~mL}$ of the same buffer, and the enzyme was eluted with a linear gradient of ammonium sulfate (30-0\% saturation, $500 \mathrm{~mL}$ each) in $10 \mathrm{~mm}$ buffer. The active fractions were combined and dialyzed against $10 \mathrm{~L}$ of $10 \mathrm{~mm}$ buffer for $12 \mathrm{~h}$. The dialyzed enzyme was applied to a column $(2 \times 15 \mathrm{~cm})$ of DEAE-Toyopearl $650 \mathrm{M}$ previously equilibrated with $10 \mathrm{~mm}$ buffer. After the column had been washed with $150 \mathrm{~mL}$ of $10 \mathrm{~mm}$ buffer, the enzyme was eluted with a linear gradient of $\mathrm{NaCl}(0-0.2 \mathrm{M}, 150 \mathrm{~mL}$ each $)$ in $10 \mathrm{~mm}$ buffer. The active fractions were combined and dialyzed against $10 \mathrm{~L}$ of $10 \mathrm{~mm}$ buffer for $12 \mathrm{~h}$. The dialyzed enzyme was applied to a column $(3 \times 15 \mathrm{~cm})$ of Gigapite (Seikagaku Kogyo, Tokyo, Japan) previously equilibrated with $10 \mathrm{~mm}$ buffer. The column was washed with $10 \mathrm{~mm}$ buffer, fractions of $10 \mathrm{~mL}$ were collected, and the active fractions were combined and concentrated. The enzyme solution was applied to a Superdex 200 HR 10/30 column (Amersham Biosciences K.K., Tokyo, Japan) equilibrated with $10 \mathrm{~mm}$ buffer containing $150 \mathrm{~mm} \mathrm{NaCl}$ and eluted with the same buffer. The active fractions were collected and dialyzed against $10 \mathrm{~L}$ of $10 \mathrm{~mm}$ buffer for $12 \mathrm{~h}$. For the determination of the $\mathrm{N}$-terminal amino acid sequence of the enzyme, the purified enzyme was covalently bound to Sequelone-arylamine and -diisothiocyanate membranes and then analyzed with a Prosequencer 6625 automatic protein sequencer (Millipore, MA, USA). 


\section{Cloning of the Pseudomonas sp. MCI3434 R-amidase gene, $\operatorname{ram} A$}

For routine work with recombinant DNA, established protocols were used [24]. Restriction endonucleases were purchased from Takara Shuzo and alkaline phosphatase from shrimp was purchased from Roche Diagnostics GmbH (Mannheim, Germany). Chromosomal DNA was prepared from Pseudomonas sp. MCI3434 by the method of Misawa et al. [25]. An oligonucleotide sense primer, 5'-TACCGCAAGACCCACCT(C/G)-3', and an antisense primer, 5'-TCCGGGAACTCGA(C/T)GTC-3', were synthesized on the basis of the amino acid sequence of the conserved region of proteins whose $\mathrm{N}$-terminal sequence is homologous to that of the R-amidase from Pseudomonas sp. MCI3434. The Expand ${ }^{\mathrm{TM}}$ high fidelity PCR system from Roche Diagnostics was used for the PCR. The reaction mixture for the PCR contained $50 \mu \mathrm{L}$ of Expand $\mathrm{HF}$ buffer with $1.5 \mathrm{mM} \mathrm{MgCl}_{2}$, each dNTP at a concentration of $0.2 \mathrm{~mm}$, the sense and antisense primers each at $1 \mu \mathrm{M}, 2.5 \mathrm{U}$ of Expand HF PCR system enzyme mix and $0.5 \mu \mathrm{g}$ of chromosomal DNA from Pseudomonas sp. MCI3434 as a template. Thirty cycles were performed, each consisting of a denaturing step at $94{ }^{\circ} \mathrm{C}$ for $30 \mathrm{~s}$ (initial cycle $2 \mathrm{~min} 30 \mathrm{~s}$ ), an annealing step at $55^{\circ} \mathrm{C}$ for $30 \mathrm{~s}$ and an elongation step at $72{ }^{\circ} \mathrm{C}$ for $2 \mathrm{~min}$. The PCR product (125 bp) was radiolabeled with $\left[\alpha-{ }^{32} \mathrm{P}\right] \mathrm{dCTP}$ using a Rediprime II DNA labeling system (Amersham Biosciences) and used as a probe for the R-amidase-encoding gene, $\operatorname{ram} A$, of Pseudomonas sp. MCI3434. Chromosomal DNA of Pseudomonas sp. MCI3434 was completely digested with FbaI or Pst $\mathrm{I}$. Southern hybridization showed a $5.5 \mathrm{~kb}$ band from $F b a \mathrm{I}$ digestion and a $2.1 \mathrm{~kb}$ band from $P$ st I digestion that hybridized with the probe. DNA fragments of 5.0-6.0 kb from the $F b a \mathrm{I}$ digestion and $2.0-2.2 \mathrm{~kb}$ from the Pst $\mathrm{I}$ digestion were recovered from $0.7 \%(\mathrm{w} / \mathrm{v})$ agarose gel by use of a QIAquick ${ }^{\mathrm{TM}}$ gel extraction kit from QIAGEN (Tokyo, Japan) and ligated into BamHI or PstI-digested and alkaline phosphatase-treated pBluescript II SK(-) using Ligation kit version 2 from Takara Shuzo. E. coli JM109 was transformed with the recombinant plasmid DNA by the method of Inoue et al. [26], and screened for the existence of the $\operatorname{ram} A$ gene by colony hybridization with the probe. Positive E. coli transformants carried an $8.5 \mathrm{~kb}$ plasmid designated pRTB1-Fba, or $5.1 \mathrm{~kb}$ plasmid designated pRTB1-Pst. Southern hybridization toward the two plasmids digested with various restriction endonucleases and preliminary nucleotide sequencing suggested that a $1.3 \mathrm{~kb}$ NaeI-FbaI fragment in pRTB1-Fba contained the entire $\operatorname{ram} A$ gene.

\section{DNA sequence analysis}

Nested unidirectional deletions were generated from a plasmid containing the $1.3 \mathrm{~kb} \mathrm{NaeI-FbaI} \mathrm{fragment} \mathrm{with} \mathrm{the}$ Kilo-Sequence deletion kit (Takara Shuzo). An automatic plasmid isolation system (Kurabo, Osaka, Japan) was used to prepare the double-stranded DNAs for sequencing. Nucleotide sequencing was performed using the dideoxynucleotide chain-termination method [27] with M13 forward and reverse oligonucleotides as primers. Sequencing reactions were carried out with a Thermo Sequenase $\mathrm{T}^{\mathrm{TM}}$ cycle sequencing kit and dNTP mixture with 7-deaza-dGTP from Amersham Biosciences, and the reaction mixtures were run on a DNA sequencer $4000 \mathrm{~L}$ (Li-cor, Lincoln, NE, USA). Both strands of DNA were sequenced. Amino acid sequences were compared with the BLAST program [28].

\section{Expression of the $\operatorname{ram} A$ gene in $E$. coli}

A modified DNA fragment coding for the R-amidase was obtained by PCR. The reaction mixture for the PCR contained in $50 \mu \mathrm{L}$ of $10 \mathrm{~mm}$ Tris/ $\mathrm{HCl}, \mathrm{pH} 8.85,25 \mathrm{~mm}$ $\mathrm{KCl}, 2 \mathrm{~mm} \mathrm{MgSO}_{4}, 5 \mathrm{~mm}\left(\mathrm{NH}_{4}\right)_{2} \mathrm{SO}_{4}$, each dNTP at a concentration of $0.2 \mathrm{~mm}$, a sense and an antisense primer each at $1 \mu \mathrm{M}, 2.5 \mathrm{U}$ of $P$ wo DNA polymerase (Roche Diagnostics) and $0.1 \mu \mathrm{g}$ of plasmid pRTB1-Fba as a template DNA. The PCR cycle was the same as that described above. The sense primer contained an HindIIIrecognition site (underlined sequence), a ribosome-binding site (double underlined sequence), and a TAG stop codon (lowercase letters) in-frame with the lac $Z$ gene in pUC19, and spanned positions 244-271 in the sequence from GenBank with accession number AB154368. The antisense primer contained an $\mathrm{XbaI}$ site (underlined sequence) and corresponded to the sequence from 1060 to 1088 . The two primers were as follows: sense primer, 5'-GGCTCAAA GCTTTAAGGAGGAAtagGAGATGAAAATTGAATT GGTGCAACTGG-3'; antisense primer, 5'-CATAGTG TTTCTAGACTTCATTGGCTGGC-3'. The amplified PCR product was digested with HindIII and $X b a \mathrm{I}$, separated by agarose gel electrophoresis and purified from the gel. The amplified DNA was inserted downstream of the lac promoter in pUC19, yielding pRTB1EX, and which was then used to transform E. coli JM109 cells.

\section{Purification of R-amidase, RamA from E. coli transformant}

E. coli JM109 harboring pRTB1EX was subcultured at $37^{\circ} \mathrm{C}$ for $12 \mathrm{~h}$ in a test tube containing $5 \mathrm{~mL}$ Luria-Bertani medium supplemented with $80 \mu \mathrm{g} \cdot \mathrm{mL}^{-1}$ ampicillin. The subculture $(5 \mathrm{~mL})$ was then inoculated into a $2 \mathrm{~L}$ Erlenmeyer flask containing $500 \mathrm{~mL}$ Luria-Bertani medium supplemented with $80 \mu \mathrm{g} \cdot \mathrm{mL}^{-1}$ ampicillin and $0.5 \mathrm{~mm}$ isopropyl thio- $\beta$-D-galactoside. After a $16 \mathrm{~h}$ incubation at $37^{\circ} \mathrm{C}$ with rotary shaking, the cells were harvested by centrifugation at $8000 \mathrm{~g}$ for $10 \mathrm{~min}$ at $4{ }^{\circ} \mathrm{C}$ and washed with $0.9 \%(\mathrm{w} / \mathrm{v}) \mathrm{NaCl}$. All the purification procedures were performed at a temperature lower than $5{ }^{\circ} \mathrm{C}$. The buffer used throughout this purification was Tris $/ \mathrm{HCl}$ buffer (pH 8.0) containing $0.1 \mathrm{~mm}$ dithiothreitol, $5 \mathrm{~mm}$ 2-mercaptoethanol and $0.1 \mathrm{~mm}$ ethylenediaminetetraacetic acid. Washed cells from a $2.5 \mathrm{~L}$ culture were suspended in $100 \mathrm{~mm}$ buffer and disrupted by sonication for $10 \mathrm{~min}$. For the removal of intact cells and cell debris, the sonicate was centrifuged at $15000 \mathrm{~g}$ for $20 \mathrm{~min}$ at $4{ }^{\circ} \mathrm{C}$. After centrifugation, the resulting supernatant was fractionated with solid ammonium sulfate. The precipitate obtained at $0-40 \%$ saturation was collected by centrifugation and dissolved in $20 \mathrm{~mm}$ buffer. The resulting enzyme solution was dialyzed against $10 \mathrm{~L}$ of the same buffer for $24 \mathrm{~h}$. The dialyzed solution was applied to a column $(2.5 \times 7 \mathrm{~cm})$ of DEAEToyopearl 650M previously equilibrated with $20 \mathrm{~mm}$ buffer. 
After the column had been washed thoroughly with $20 \mathrm{~mm}$ buffer, followed by the same buffer containing $50 \mathrm{~mm}$ $\mathrm{NaCl}$, the enzyme was eluted with $100 \mathrm{~mL}$ of $20 \mathrm{~mm}$ buffer containing $100 \mathrm{~mm} \mathrm{NaCl}$. The active fractions were combined and dialyzed against $10 \mathrm{~L}$ of $20 \mathrm{~mm}$ buffer for $12 \mathrm{~h}$. The enzyme solution was applied to a MonoQ HR 10/10 column (Amersham Biosciences KK) previously equilibrated with $20 \mathrm{~mm}$ buffer. After the column had been washed with $30 \mathrm{~mL}$ of $20 \mathrm{~mm}$ buffer, the enzyme was eluted with a linear gradient of $\mathrm{NaCl}(0-0.5 \mathrm{M})$ in $20 \mathrm{~mm}$ buffer using an ÄKTA-FPLC system (Amersham Biosciences $\mathrm{KK})$. The active fractions were combined and dialyzed against $10 \mathrm{~L}$ of $20 \mathrm{~mm}$ buffer for $12 \mathrm{~h}$ and used for characterization.

\section{Enzyme assay}

During the purification of the amidase from Pseudomonas sp. MCI3434, the enzyme assay was carried out with $(R, S)$-piperazine-2-tert-butylcarboxamide as a substrate. The reaction mixture $(0.1 \mathrm{~mL})$ contained $10 \mu \mathrm{mol}$ potassium phosphate buffer $(\mathrm{pH} 7.0), 5.4 \mu \mathrm{mol}(R, S)$ piperazine-2-tert-butylcarboxamide and an appropriate amount of the enzyme. After the reaction was performed at $30{ }^{\circ} \mathrm{C}$ for $5-10 \mathrm{~h}$, the piperazine-2-carboxylic acid formed was derivatized with 4-chloro-7-nitro-2,1,3-benzoxadiazole (NBD-Cl) by the addition of $100 \mu \mathrm{L}$ of $0.1 \% \mathrm{NBD}-\mathrm{Cl}$ in methanol, $100 \mu \mathrm{L}$ of $0.1 \mathrm{M} \mathrm{NaHCO}_{3}$, and $500 \mu \mathrm{L}$ of $\mathrm{H}_{2} \mathrm{O}$ to the reaction mixture. After incubation at $55^{\circ} \mathrm{C}$ for $1 \mathrm{~h}$, the amount of derivatized piperazine-2-carboxylic acid was determined with an HPLC apparatus equipped with an ODS-80Ts column $(0.46 \times 150 \mathrm{~cm}$; Tosoh Corp., Tokyo, Japan) at a flow rate of $0.6 \mathrm{~mL} \cdot \mathrm{min}^{-1}$, using as a solvent system methanol $/ 5 \mathrm{~mm} \mathrm{H}_{3} \mathrm{PO}_{4}(2: 3, \mathrm{v} / \mathrm{v})$. The eluate was detected spectrofluorometrically with an excitation wavelength of $503 \mathrm{~nm}$ and an emission wavelength of $541 \mathrm{~nm}$. One unit of enzyme activity was defined as the amount catalyzing the formation of $1 \mu \mathrm{mol}$ piperazine-2carboxylic acid $\cdot \mathrm{min}^{-1}$ from $(R, S)$-piperazine-2-tert-butylcarboxamide under the above conditions. Protein was determined by the method of Bradford [29] with BSA as standard, using a kit from Bio-Rad Laboratories Ltd (Tokyo, Japan).

For determination of the stereochemistry of the reaction product, a chiral-separation column was used in HPLC. The reaction mixture $(1 \mathrm{~mL})$ contained $100 \mu \mathrm{mol}$ potassium phosphate buffer ( $\mathrm{pH} 7.0), 10 \mu \mathrm{mol}(R, S)$-piperazine-2-tertbutylcarboxamide and an appropriate amount of the cell or enzyme. The reaction was performed at $30^{\circ} \mathrm{C}$ and stopped by the addition of $1 \mathrm{~mL}$ of ethanol. The amount of each enantiomer of the piperazine-2-carboxylic acid formed in the reaction mixture was determined with an HPLC apparatus equipped with a Sumichiral OA-5000 column $(0.46 \times 15 \mathrm{~cm}$; Sumika Chemical Analysis Service, Osaka, Japan) at a flow rate of $1.0 \mathrm{~mL} \cdot \mathrm{min}^{-1}$, using as a solvent system $2 \mathrm{~mm} \mathrm{CuSO}_{4}$. The absorbance of the eluate was monitored at $254 \mathrm{~nm}$.

$(R, S)$-Piperazine-2-carboxamide was used as a substrate during the purification and characterization of recombinant RamA from E. coli transformant. The reaction mixture $(1 \mathrm{~mL})$ contained $100 \mu \mathrm{mol}$ Tris/ $\mathrm{HCl}$ buffer (pH 8.0), $20 \mu \mathrm{mol}(R, S)$-piperazine-2-carboxamide and an appropriate amount of the enzyme. The reaction was performed at $30{ }^{\circ} \mathrm{C}$ for $5-15 \mathrm{~min}$ and stopped by the addition of $1 \mathrm{~mL}$ ethanol. The amount of piperzine-2-carboxylic acid formed in the reaction mixture was determined with the HPLC apparatus equipped with a Sumichiral OA-5000 column as described above. One unit of enzyme activity was defined as the amount catalyzing the formation of $1 \mu \mathrm{mol}$ piperazine-2-carboxylic acid $\mathrm{min}^{-1}$ from $(R, S)$-piperazine-2carboxamide under the above conditions.

Enzyme activity toward other amide and nitrile compounds was determined by measuring the formation of ammonia. The amount of ammonia produced was colorimetrically determined by the phenol/hypochlorite method [30] using Conway microdiffusion apparatus [31]. Enzyme activity toward dipeptides was determined by measuring the production of amino acids by thin-layer chromatography with a solvent system (1-butanol/acetic acid/water; $4: 1: 1$ ). The amounts of $\beta$-alanine, D-glutamic acid amide and D-glutamine were quantitatively assayed by HPLC as described for the $(R, S)$-piperazine-2-carboxylic acid. The amounts of $(R, S)$-piperidine-3-carboxylic acid and piperidine-4-carboxylic acid were assayed after derivatization with NBD-Cl by the same method described for $(R, S)$ piperazine-2-carboxylic acid.

\section{Analytical measurements}

To estimate the molecular mass of the enzyme, the sample $(3 \mu \mathrm{g})$ was subjected to HPLC on a TSK G-3000 SW column $(0.75 \times 60 \mathrm{~cm}$; Tosoh Corp. $)$ at a flow rate of $0.6 \mathrm{~mL} \cdot \mathrm{min}^{-1}$ with $0.1 \mathrm{M}$ sodium phosphate $(\mathrm{pH} 7.0)$ containing $0.1 \mathrm{M} \mathrm{Na}_{2} \mathrm{SO}_{4}$ at room temperature. The absorbance of the eluate was monitored at $280 \mathrm{~nm}$. The molecular mass of the enzyme was then calculated based on relative mobility (retention time) using the standard proteins glutamate dehydrogenase (290 kDa), lactate dehydrogenase $(142 \mathrm{kDa})$, enolase $(67 \mathrm{kDa})$, adenylate kinase $(32 \mathrm{kDa})$ and cytochrome $c(12.4 \mathrm{kDa})$ (Oriental Yeast Co., Tokyo, Japan). SDS/PAGE analysis was performed by the method of Laemmli [32]. Proteins were stained with Brilliant blue $\mathrm{G}$ and destained in ethanol/acetic acid/water $(3: 1: 6, \mathrm{v} / \mathrm{v} / \mathrm{v})$.

\section{Nucleotide sequence accession number}

The nucleotide sequence data reported in this paper will appear in the DDBJ/EMBL/GenBank nucleotide sequence database with the accession number AB154368.

\section{Results}

\section{Purification and characterization of the $R$-stereoselective amidase from Pseudomonas sp. $\mathrm{MCl} 3434$}

An amidase, acting on piperazine-2-tert-butylcarboxamide was detected in Pseudomonas sp. MCI3434. Various nitrogen and carbon sources were tested, and the highest level of activity was obtained after culture in an optimized medium, Medium I, containing Bonito extract and DL-malate. No amide compounds enhanced the amidase activity in the cells, suggesting a constitutive expression of the amidase. HPLC analysis with a Sumichiral OA-5000 column showed that the Pseudomonas sp. MCI3434 cells acted on racemic 


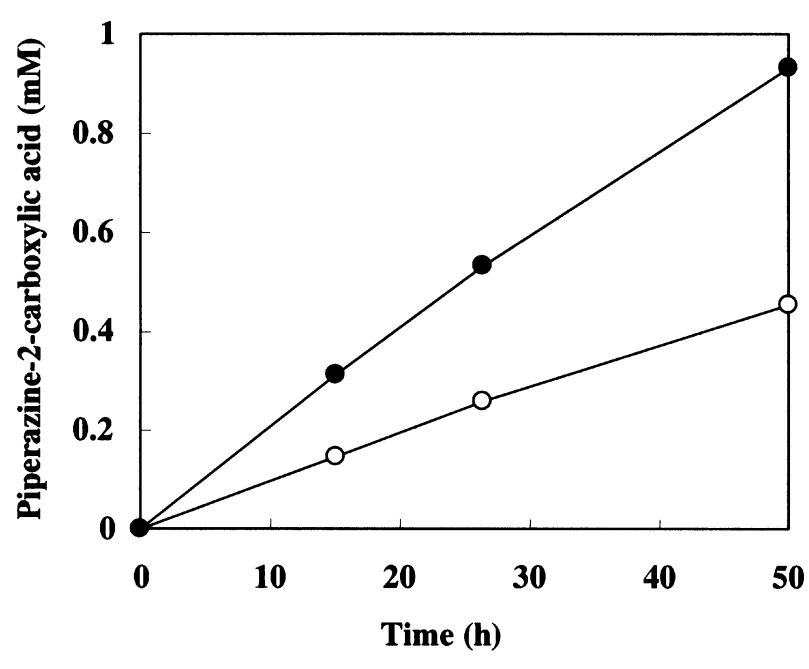

Fig. 2. Hydrolysis of racemic piperazine-2-tert-butylcarboxamide by cells of Pseudomonas sp. MCI3434. Pseudomonas sp. MCI3434 was cultured in $200 \mathrm{~mL}$ of medium $\mathrm{I}$ for $12 \mathrm{~h}$ at $30^{\circ} \mathrm{C}$. The cells were then harvested, washed with $0.9 \% \mathrm{NaCl}$, and suspended in $3 \mathrm{~mL}$ of $0.1 \mathrm{M}$ potassium phosphate ( $\mathrm{pH} 7.0$ ). The reaction mixture contained $10 \mathrm{~mm}$ of piperazine-2-tert-butylcarboxamide, $150 \mu \mathrm{L}$ of the cell suspension and $0.1 \mathrm{M}$ of potassium phosphate $(\mathrm{pH} 7.0)$ in a total volume of $200 \mu \mathrm{L}$, and was incubated at $30^{\circ} \mathrm{C}$. The reaction was stopped at a specific time and the concentration of each enantiomer of piperazine-2carboxylic acid formed was determined using HPLC with a Sumichiral OA-5000 column as described in Materials and methods. $\bullet,(R)$-piperazine-2-carboxylic acid; $\bigcirc,(S)$-piperazine-2-carboxylic acid.

piperazine-2-tert-butylcarboxamide to produce $(R)$ - and $(S)$-piperazine-2-carboxylic acid, with a preference for the $R$-form (Fig. 2).

To investigate the stereoselectivity of the hydrolytic activity toward the substrate, the amidase was purified from a cell-free extract of Pseudomonas sp. MCI3434 as described in Materials and methods with a recovery of $0.07 \%$ (Table 1). The final preparation gave a single band on SDS/PAGE with a molecular mass of $\approx 29.5 \mathrm{kDa}$. The molecular mass of the native enzyme was about $36 \mathrm{kDa}$ according to gel-filtration chromatography, indicating that the native enzyme was a monomer. The purified enzyme catalyzed the hydrolysis of piperazine-2-tert-butylcarboxamide with strict $R$-stereoselectivity (Fig. 3). This result suggests that the strain can express another amidase acting

Table 1. Purification of R-amidase from Pseudomonas sp. MCI3434. $R, S$-Piperazine-2-tert-butylcarboxamide was used as a substrate for total and specific activity.

\begin{tabular}{|c|c|c|c|c|}
\hline Step & $\begin{array}{l}\text { Total } \\
(\mathrm{mg})\end{array}$ & $\begin{array}{l}\text { Total } \\
\text { protein } \\
(\mathrm{mU})\end{array}$ & $\begin{array}{l}\text { Specific } \\
\text { activity } \\
\left(\mathrm{mU} \cdot \mathrm{mg}^{-1}\right)\end{array}$ & $\begin{array}{l}\text { Yield } \\
\text { activity } \\
(\%)\end{array}$ \\
\hline Cell-free extract & 6700 & 400 & 0.06 & 100 \\
\hline DEAE-Toyopearl (first) & 1520 & 230 & 0.151 & 57.5 \\
\hline Butyl-Toyopearl & 107 & 32 & 0.299 & 8.0 \\
\hline DEAE-Toyopearl (second) & 25 & 31 & 1.24 & 7.8 \\
\hline Gigapite & 2.5 & 6.4 & 2.56 & 1.6 \\
\hline Superdex 200 HR $10 / 30$ & 0.012 & 0.29 & 24.2 & 0.07 \\
\hline
\end{tabular}

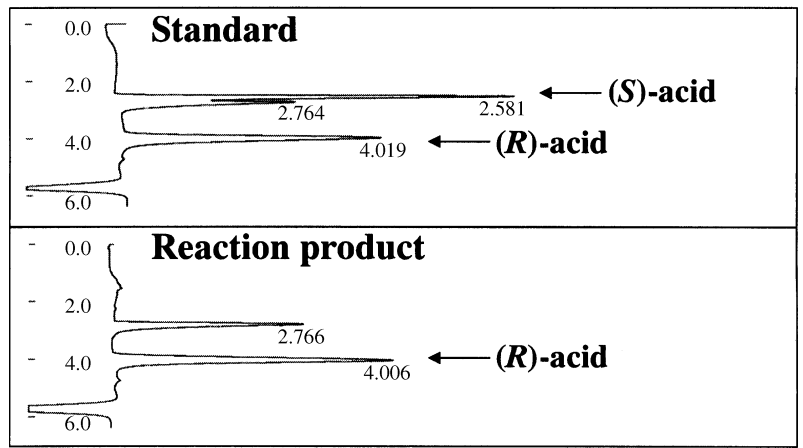

Fig. 3. Stereochemical analysis of piperazine-2-carboxylic acid produced by the purified $\mathbf{R}$-amidase. The reaction mixture contained $10 \mathrm{~mm}$ of piperazine-2-tert-butylcarboxamide, $2 \mu \mathrm{g}$ of the purified R-amidase, and $0.1 \mathrm{M}$ of potassium phosphate $(\mathrm{pH} 7.0)$ in a total volume of $200 \mu \mathrm{L}$, and was incubated at $30^{\circ} \mathrm{C}$ for $10 \mathrm{~h}$. The stereochemistry of the piperazine-2-carboxylic acid formed was determined using HPLC with Sumichiral OA-5000 column as described in Materials and methods. The substrate amides were not detected in these HPLC conditions.

on the racemic substrate with $S$-stereoselectivity or without stereoselectivity. The $R$-stereoselective enzyme was tentatively named $\mathrm{R}$-amidase.

\section{Cloning and characterization of the R-amidase gene, $\operatorname{ramA}$}

To obtain information about the primary structure of the R-amidase, its N-terminal amino acid sequence was analyzed by Edman degradation and found to be MetAla-Ile-Glu-Leu-Val-Gln-Leu-Ala-Gly-Arg-Asp-Gly-Asp. A BLAST search of a protein database indicated that the $\mathrm{N}$-terminal amino acid sequence of R-amidase showed high sequence identity (11 of 14 amino acid residues identical) with that of a hypothetical hydrolase encoded by the PA3598 gene found in the complete genome sequence of Pseudomonas aeruginosa strain PAO1 [33]. The deduced amino acid sequence of PA3598 has similarity with the putative hydrolase Q9L104 from Streptomyces coelicolor A3(2) [34] and a hypothetical $31.2 \mathrm{kDa}$ protein, YPQQ in the pqqf 5' region of Pseudomonas fluorescens CHA0 [35]. Two highly conserved regions among the PA3598, Q9L104, and YPQQ sequences, Tyr106-Arg-Lys-ThR-His-Leu and Asp142-(Ile or Val)-Glu-Phe-Pro-Glu (numbering of the first residues are based on the PA3598 sequence), were considered to be also present in the R-amidase sequence. The primers used for cloning part of the R-amidase gene, named $\operatorname{ram} A$, by PCR were designed based on the conserved regions. A 125-bp DNA was PCR-amplified with the primers and the chromosomal DNA prepared from Pseudomonas sp. MCI3434 and used as a probe for Southern and colony hybridizations to obtain the recombinant plasmids pRTB1-Fba and pRTB1-Pst which contain inserts of 5.3 and $2.1 \mathrm{~kb}$, respectively. Southern hybridization of the two plasmids digested with various restriction endonucleases and preliminary nucleotide sequencing showed that a 1.3-kb NaeI-FbaI fragment in pRTB1-Fba contained the entire $\operatorname{ram} A$ gene. Two inserts from $\mathrm{pRTB} 1-$ 


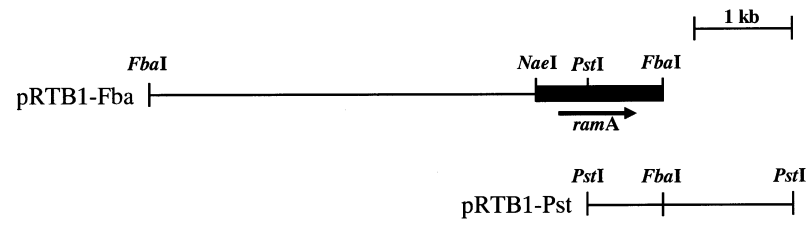

Fig. 4. Schematic view of the inserted fragments of pRTB1-Fba and pRTB1-Pst. For clarity, only restriction sites discussed in the text are shown. The location of $\operatorname{ram} A$ and its direction of transcription are indicated by an arrow. The NaeI-FbaI fragment sequenced in this study is indicated by a black box.

Fba and pRTB1-Pst were also found to share a common PstI-FbaI region (Fig. 4).

The nucleotide sequence of the NaeI-FbaI fragment was determined to be 1332-bp long, and an open reading frame (ORF) was present in this region. The $\mathrm{N}$-terminal sequence deduced from the ORF is consistent with the sequence determined by peptide sequencing of the purified R-amidase, except for the second lysine residue. The structural ramA gene consists of 822 bp and codes for a protein of 274 amino acids with a predicted molecular mass of 30128 Da, which is consistent with the value estimated from the relative mobility of the purified R-amidase on SDS/PAGE. A potential ribosome-binding site (AGGA) was located just seven nucleotides upstream from the start codon ATG. In the upstream region of the $\operatorname{ram} A$ translational start codon, sequences related to the -35 (TTTATT) and -10 (CATACT) consensus promoter regions were identified.

An alignment with the SwissProt and NBRF-PIR databases using the BLAST program showed that in primary structure, R-amidase is similar to the putative carbonnitrogen hydrolase family proteins PP3846 from Pseudomonas putida strain KT2440 [72.6\% identical over 270 amino acids [36]; TrEMBL accession number Q88G79], PA3598 from $P$. aeruginosa strain PAO1 [65.6\% identical over 270 amino acids [33]; PIR accession number H83195], PP0382 from $P$. putida strain KT2440 [40.8\% identical over 260 amino acids [36]; TrEMBL accession number Q88QV2], R02496 from Sinorhizobium meliloti strain 1021 [36.9\% identical over 255 amino acids [37]; TrEMBL accession number Q92MW3], SAV6892 from Streptomyces avermitilis strain MA-4680 [36.2\% identical over 260 amino acids [38]; TrEMBL accession number Q827N2], and a $31.2 \mathrm{kDa}$ protein in the $p q q F 5$ ' region of Pseudomonas fluorescens strain CHA0 [36.8\% identical over 266 amino acids [35]; SwissProt accession number YPQQ_PSEFL]. Figure 5
Fig. 5. Comparison of the amino acid sequences of the R-amidase (RamA) and homologous proteins. Identical and conserved amino acids among the sequences are marked in black and in gray, respectively. Dashed lines indicate the gaps introduced for better alignment. Invariant catalytic triad residues,

glutamic acid, lysine and cysteine in the carbon-nitrogen hydrolase family are marked by asterisks. RamA, R-amidase from Pseudomonas sp. MCI3434; PP3846, carbon-nitrogen hydrolase PP3846 from Pseudomonas putida strain KT2440; PA3598, conserved hypothetical protein PA3598 from Pseudomonas aeruginosa strain PAO1; PP0382, carbon-nitrogen hydrolase PP0382 from Pseudomonas putida strain KT2440; YPQQ, carbon-nitrogen hydrolase in the $p q q F 5^{\prime}$ region of Pseudomonas fluorescens strain CHA0; SAV6892, putative hydrolase SAV6892 from Streptomyces avermitilis strain MA-4680; R02496, hypothetical protein R02496 from Sinorhizobium meliloti strain 1021.
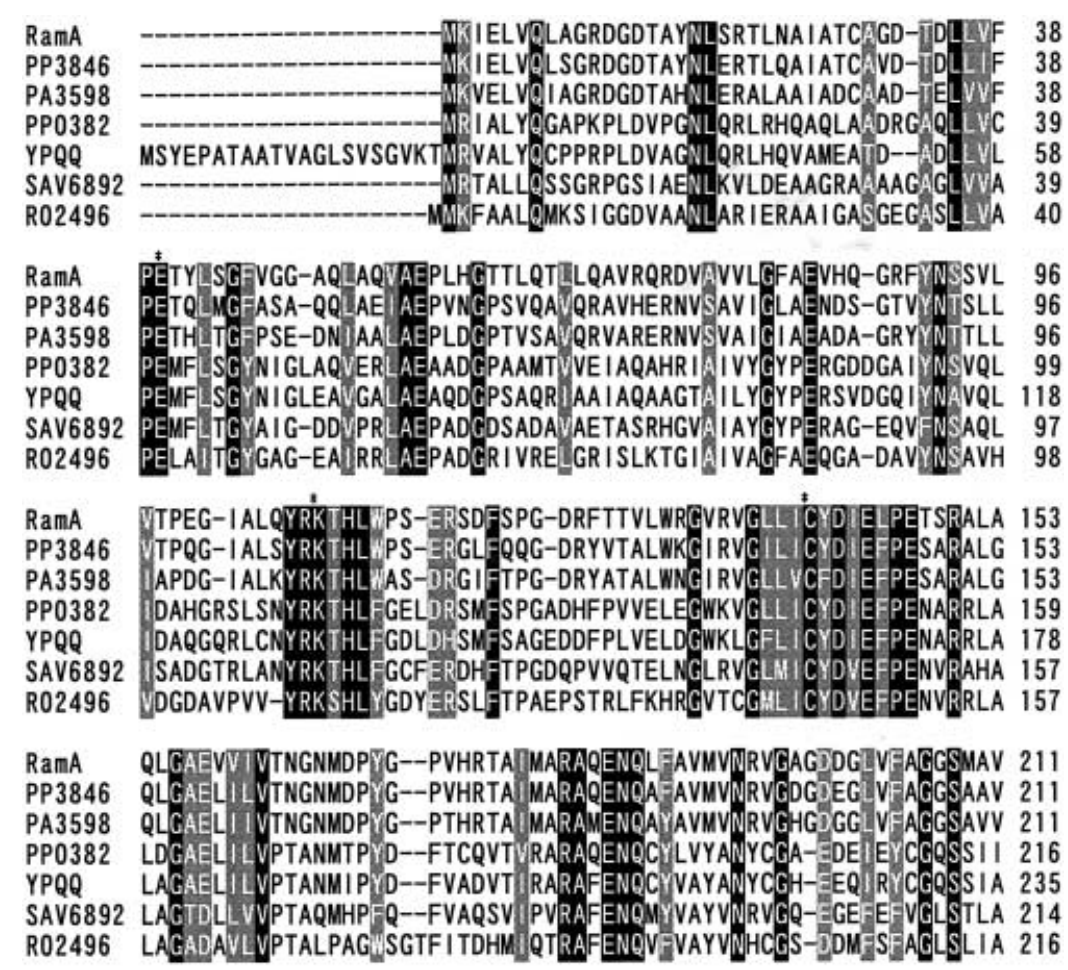

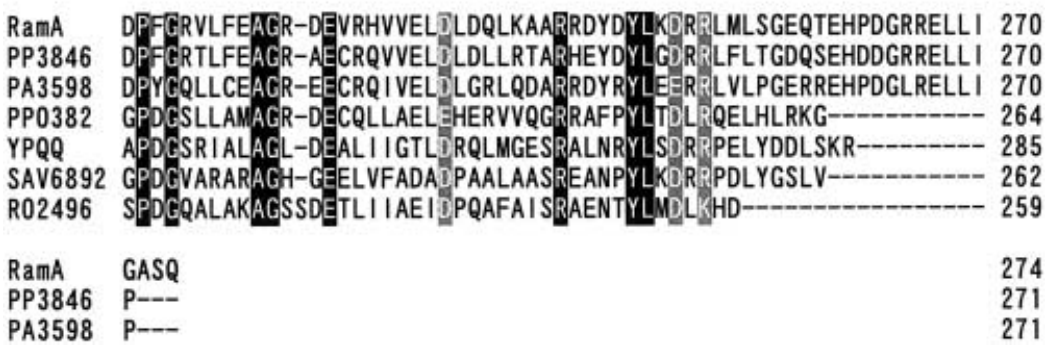


shows the alignment of the primary structure of the R-amidase from Pseudomonas sp. MCI3434 and above sequences. All the sequences except for RamA in the figure were hypothetical proteins found in the genome sequence but yet to be characterized functionally. The most closely related characterized enzyme was $P$. aeruginosa aliphatic amidase [26.5\% identical over 249 amino acids [1]; Genbank accession number M27612] which also belongs to the carbon-nitrogen hydrolase family. No significant homology was observed with the other amidases mentioned in the introduction section. The conserved motifs of the carbonnitrogen hydrolase family [39] surrounding the probable catalytic triad, Glu40, Lys108, and Cys140 were highly conserved in the RamA sequence.

\section{Production of the R-amidase in $E$. coli and optical resolution of racemic piperazine-2-tert- butylcarboxamide by the recombinant $E$. coli cells}

The direction of $\operatorname{ram} A$ transcription was opposite to that of the lac promoter in pRTB1-Fba. E. coli JM109 transformed by the recombinant plasmid exhibited no amidase activity toward $(R, S)$-piperazine-2-tert-butylcarboxamide. These findings suggest that RNA polymerase in E. coli can not recognize the promoter for $\operatorname{ram} A$ or that there is a possible regulatory gene in the inserted fragment of pRTB1-Fba. To express the $\operatorname{ram} A$ gene in $E$. coli, we improved the sequence upstream from the ATG start codon by PCR, with the plasmid pRTB1-Fba as a template as described in Materials and methods. The resultant plasmid, pRTB1EX, in which the $\operatorname{ram} A$ gene was under the control of the lac promoter of the pUC19 vector, was introduced into $E$. coli JM109 cells. A protein band $(29.5 \mathrm{kDa})$ corresponding to the R-amidase purified from Pseudomonas sp. MCI3434 was produced when the lac promoter was induced by isopropyl- $\beta$ D-thiogalactopyranoside (data not shown). When E. coli JM109 harboring pRTB1EX was cultured in Luria-Bertani medium supplemented with ampicillin and isopropyl- $\beta$ D-thiogalactopyranoside for $15 \mathrm{~h}$ at $37^{\circ} \mathrm{C}$, the level of RamA activity toward $(R, S)$-piperazine-2-tert-butylcarboxamide in the supernatant of the sonicated cell-free extract of the transformant was 1.81 units $\mathrm{mg}^{-1}$, which is about 30000 times higher than that of Pseudomonas sp. MCI3434. The cell reaction with $0.2 \mathrm{M}$ of racemic piperazine-2-tert-butylcarboxamide was carried out using two concentrations of $E$. coli cells ( 0.43 and $2.2 \%$, weight of wet cells/volume) prepared from the $15 \mathrm{~h}$ culture (Fig. 6). The $E$. coli cells produced $(R)$-piperazine-2-carboxylic acid with high optical purity $(>99.5 \%$ ee) at all the reaction times tested.

\section{Purification of RamA from E. coli transformant}

Recombinant RamA was purified from the E. coli JM109 harboring pRTB1EX with a recovery of $17.9 \%$ by ammonium sulfate fractionation and DEAE-Toyopearl and MonoQ column chromatographies (Table 2). The final preparation gave a single band on SDS/PAGE with a molecular mass of $\approx 29.5 \mathrm{kDa}$ (Fig. 7). This value is the same as that for the R-amidase purified from Pseudomonas sp. MCI3434 and in good agreement with that estimated from the deduced amino acid sequence of the

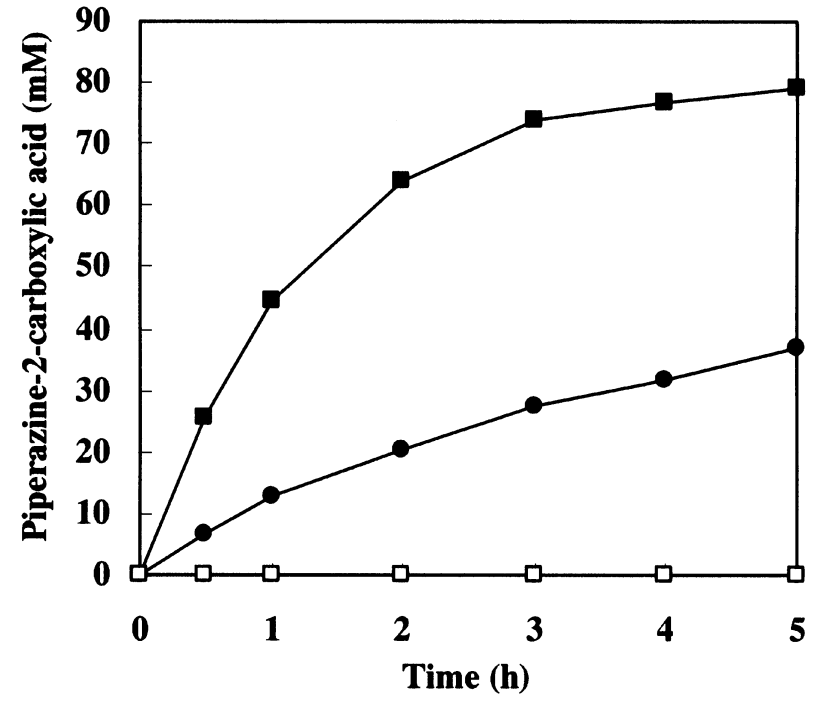

Fig. 6. Stereoselective hydrolysis of racemic piperazine-2-tert-butylcarboxamide by cells of $\boldsymbol{E}$. coli JM109/pRTB1EX. The reaction mixture contained $0.2 \mathrm{M}$ of racemic piperazine-2-tert-butylcarboxamide, washed $E$. coli cells prepared from the culture broth after $12 \mathrm{~h}$ cultivation, and $0.1 \mathrm{M}$ of Tris $/ \mathrm{HCl}(\mathrm{pH} \mathrm{8.0)}$ in a total volume of $800 \mu \mathrm{L}$, and was incubated at $30{ }^{\circ} \mathrm{C}$. The reaction was stopped at a specific time and the concentration of piperazine-2-carboxylic acid formed was determined as described in Materials and methods. $\bigcirc,(R)$-acid formed with cells $(0.43 \%$, weight of wet cells/volume); $\mathbf{\square},(R)$-acid formed with cells $(2.2 \%, \mathrm{w} / \mathrm{v}) ; \square,(S)$-acid formed with cells $(2.2 \%$, w/v). The cell density $(0.43 \%, \mathrm{w} / \mathrm{v})$ corresponds to the concentration of cells harvested from $800 \mu \mathrm{L}$ of culture broth used in $800 \mu \mathrm{L}$ of reaction mixture.

Table 2. Purification of RamA from $E$. coli JM109 harboring pRTB1EX. Piperazine-2 carboxamide was used as a substrate for total and specific activity.

\begin{tabular}{llllc}
\hline & $\begin{array}{l}\text { Total } \\
\text { protein } \\
(\mathrm{mg})\end{array}$ & $\begin{array}{l}\text { Total } \\
\text { activity } \\
(\mathrm{U})\end{array}$ & $\begin{array}{l}\text { Specific } \\
\text { activity } \\
\left(\mathrm{U} \cdot \mathrm{mg}^{-1}\right)\end{array}$ & $\begin{array}{l}\text { Yield } \\
(\%)\end{array}$ \\
\hline Cell free extract & 1890 & 3420 & 1.81 & 100 \\
Ammonium sulfate & 1210 & 3190 & 2.64 & 93.3 \\
DEAE-Toyopearl & 246 & 853 & 3.47 & 24.9 \\
MonoQ HR10/10 & 134 & 614 & 4.59 & 17.9 \\
\hline
\end{tabular}

RamA. The molecular mass of the native enzyme was again about $36 \mathrm{kDa}$ according to gel-filtration chromatography, indicating that the native enzyme was a monomer. The purified enzyme catalyzed the hydrolysis of $(R, S)$-piperazine-2-carboxamide to $(R)$-piperazine-2carboxylic acid at $4.59 \mathrm{U} \cdot \mathrm{mg}^{-1}$ under the standard conditions.

\section{Effects of temperature and $\mathrm{pH}$ on the stability and activity of RamA}

The purified enzyme could be stored without loss of activity for more than 2 months at $-20{ }^{\circ} \mathrm{C}$ in the buffer containing $50 \%$ glycerol. The stability of the enzyme was examined at various temperatures. After the enzyme had been 


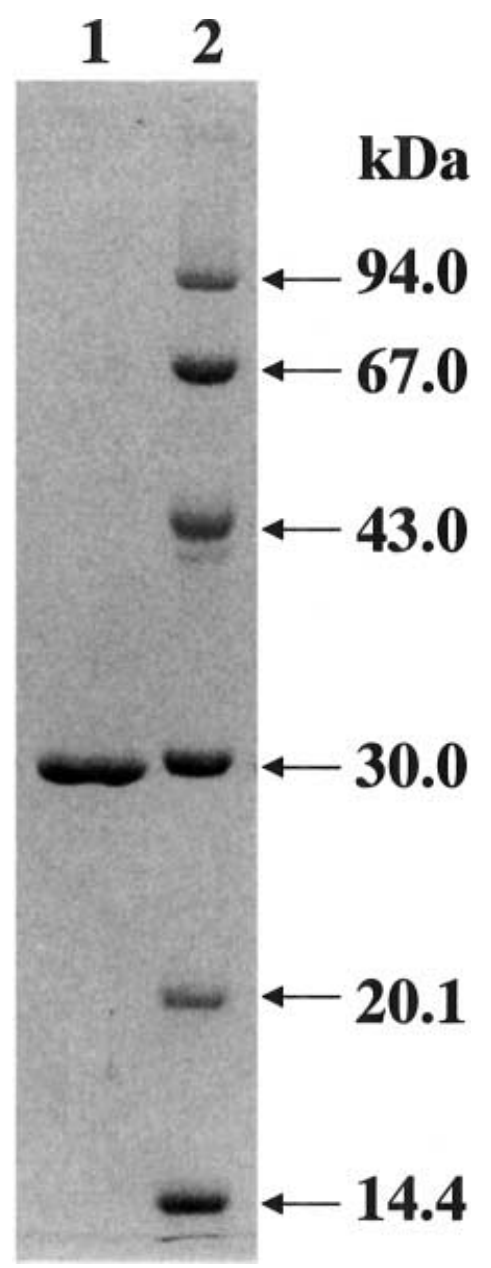

Fig. 7. SDS/PAGE of recombinant R-amidase purified from the $E$. coli transformant. Lane 1, purified enzyme $(10 \mu \mathrm{g})$; lane 2, molecular mass standards [phosphorylase b $(94 \mathrm{kDa})$, BSA $(67 \mathrm{kDa})$, ovalbumin $(43 \mathrm{kDa})$, carbonic anhydrase $(30 \mathrm{kDa})$, soybean trypsin inhibitor $(20 \mathrm{kDa})$ and $\alpha$-lactalbumin $(14.4 \mathrm{kDa})]$.

preincubated for $10 \mathrm{~min}$, the activity was assayed with $(R, S)$-piperazine-2-carboxamide as a substrate under the standard conditions. It exhibited the following remaining activity: $55^{\circ} \mathrm{C}, 0 \% ; 50{ }^{\circ} \mathrm{C}, 2.6 \% ; 45^{\circ} \mathrm{C}, 87 \% ; 40{ }^{\circ} \mathrm{C}$, $100 \% ; 35^{\circ} \mathrm{C}, 100 \%$. The stability of the enzyme was also examined at various $\mathrm{pH}$ values. The enzyme was incubated at $30{ }^{\circ} \mathrm{C}$ for $10 \mathrm{~min}$ in the following buffers (final concentration $100 \mathrm{~mm}$ ): acetic acid/sodium acetate ( $\mathrm{pH} 4.0-6.0)$, Mes/ $\mathrm{NaOH}(\mathrm{pH} 5.5-6.5)$, potassium phosphate $(\mathrm{pH} 6.5-$ 8.5), Tris/ $\mathrm{HCl}(\mathrm{pH} 7.5-9.0)$, ethanolamine/ $\mathrm{HCl}(\mathrm{pH} 9.0-$ 11.0) and glycine $/ \mathrm{NaCl} / \mathrm{NaOH}(\mathrm{pH} 10.0-13.0)$. Then a sample of the enzyme solution was taken, and the remaining activity of RamA was assayed with $(R, S)$-piperazine-2carboxamide as a substrate under the standard conditions. The enzyme was most stable in the $\mathrm{pH}$ range 6.0-9.0.

The enzyme reaction was carried out at various temperatures for $5 \mathrm{~min}$ in $0.1 \mathrm{M}$ Tris $/ \mathrm{HCl}(\mathrm{pH} 8.0$ ), and enzyme activity was found to be maximal at $45^{\circ} \mathrm{C}$. Above $45^{\circ} \mathrm{C}$, it decreased rapidly, possibly because of instability of the enzyme at the higher temperatures. The optimal $\mathrm{pH}$ for the activity of the enzyme was measured in the buffers described above. The enzyme showed maximum activity at $\mathrm{pH} 9.0$.

\section{Effects of inhibitors and metal ions}

The RamA solution was dialyzed against $20 \mathrm{~mm}$ Tris/HCl ( $\mathrm{pH}$ 8.0). Various compounds were investigated for their effects on enzyme activity. We measured the enzyme activity under standard conditions after incubation at $30{ }^{\circ} \mathrm{C}$ for $10 \mathrm{~min}$ with various compounds at $1 \mathrm{~mm}$. The enzyme was completely inhibited by $p$-chloromercuribenzoate, $\mathrm{N}$-ethylmaleimide, $\mathrm{MnSO}_{4}, \mathrm{MnCl}_{2}, \mathrm{CoCl}_{2}, \mathrm{NiCl}_{2}, \mathrm{CuSO}_{4}, \mathrm{CuCl}_{2}$, $\mathrm{ZnSO}_{4}, \mathrm{ZnCl}_{2}, \mathrm{AgNO}_{3}, \mathrm{CdCl}_{2}, \mathrm{HgCl}_{2}$ and $\mathrm{PbCl}_{2}$ and inhibited $78 \%$ by $\mathrm{FeCl}_{3}$ and $67 \%$ by $\mathrm{Fe}\left(\mathrm{NH}_{4}\right)_{2}\left(\mathrm{SO}_{4}\right)_{2}$, suggesting the presence of a catalytic cysteine residue. Dithiothreitol had a little enhancing effect $(138 \%)$ on the enzyme activity. Inorganic compounds such as $\mathrm{LiBr}$, $\mathrm{H}_{2} \mathrm{BO}_{3}, \mathrm{NaCl}, \mathrm{MgSO}_{4}, \mathrm{MgCl}_{2}, \mathrm{AlCl}_{3}, \mathrm{KCl}, \mathrm{CaCl}_{2}, \mathrm{CrCl}_{3}$, $\mathrm{RbCl}, \mathrm{Na}_{2} \mathrm{MoO}_{4}\left(\mathrm{NH}_{4}\right)_{6} \mathrm{Mo}_{7} \mathrm{O}_{24}, \mathrm{CsCl}$ and $\mathrm{BaCl}_{2}$ did not influence the activity. Chelating reagents, e.g. $o$-phenanthroline, 8-hydroxyquinoline, ethylenediaminetetraacetic acid and $\alpha, \alpha^{\prime}$-dipyridyl had no significant effect on the enzyme. Carbonyl reagents such as hydroxylamine, phenylhydrazine, hydrazine, D,L-penicillamine and D-cycloserine were not inhibitory toward the enzyme. A serine protease inhibitor, phenylmethanesulfonyl fluoride, a serine/cysteine protease inhibitor, leupeptine and an aspartic protease inhibitor, pepstatin did not influence the activity.

\section{Substrate specificity}

To study the substrate specificity, the purified RamA was used to hydrolyze various amides, dipeptides and nitriles, and the activity was assayed (Table 3 ). The enzyme hydrolyzed $(R, S)$-piperazine-2-carboxamide and $(R, S)$-piperazine-2-tert-butylcarboxamide with strict $R$-stereoselectivity

Table 3. Substrate specificity of RamA purified from E. coli JM109 harboring pRTB1EX. The activity for $(R, S)$-piperazine-2-carboxamide, corresponding to $4.59 \mathrm{U} \cdot \mathrm{mg}^{-1}$, was taken as $100 \%$. Amino or imino nitrogen atoms which appeared to be recognized by RamA are written in bold type.

(R,S)-Piperazine-2-tert-butylcarboxamide Relative activity (\%),
$\begin{aligned} & \text { (R,S)-Piperidine-3-carboxamide } \\ & \text { Pipecotamide) } \\ & \text { (Isonipecotamide) }\end{aligned}$


to produce only $(R)$-piperazine-2-carboxylic acid. Besides the two substrates, the enzyme was also active towards $\beta$-alaninamide, $(R, S)$-piperidine-3-carboxamide and D-glutaminamide, and slightly active on L-glutaminamide and piperidine-4-carboxamide. When both of the glutaminamide enantiomers were used as substrates, the reaction products of hydrolysis were corresponding enantiomers of glutamic acid amides, not glutamines. Considering the structural formulae of the above substrates, RamA seemed to recognize the carboxamide substrates in which the amino or imino group is connected to $\beta$ - or $\gamma$-carbon of the compounds. The enzyme could not hydrolyze the following D- and L-amino acid amides: D-alaninamide, D-valinamide, D-leucinamide, D-isoleucinamide, D-prolinamide, D-phenylalaninamide, D-tryptophanamide, D-methioninamide, D-serinamide, D-threoninamide, D-tyrosinamide, D-aspartic acid amide, D-glutamic acid amide, D-lysinamide, D-argininamide, D-histidinamide, L-alaninamide, L-valinamide, L-leucinamide, L-isoleucinamide, L-prolinamide, L-phenylalaninamide, L-tryptophanamide, L-methioninamide, L-serinamide, L-threoninamide, L-tyrosinamide, L-asparaginamide, L-aspartic acid amide, L-glutamic acid amide, L-lysinamide, L-argininamide, L-histidinamide, glycinamide and $(R, S)$ piperidine-2-carboxamide. Carboxamides of the side chains in D-asparagine, D-glutamine, L-asparagine and L-glutamine were not hydrolyzed by the enzyme. The enzyme did not show peptidase activity toward $\beta$-alanyl-L-alanine, $\beta$-alanylglycine, $\beta$-alanyl-L-histidine, glycylglycine, glycylglycylglycine, L-alanylglycine, D-alanylglycine, D-alanylglycylglycine, DL-alanyl-DL-asparagine, DL-alanyl-DL-isoleucine, DL-alanyl-DL-leucine, DL-alanyl-DL-methionine, DL-alanylDL-phenylalanine, DL-alanyl-DL-serine, DL-alanyl-DL-valine and L-aspartyl-D-alanine. Although the RamA showed high sequence similarity with the hypothetical proteins in the carbon-nitrogen hydrolase family, the enzyme could not hydrolyze the following aliphatic amides, aromatic amides and nitriles: acetamide, propionamide, $n$-butyramide, isobutyramide, $n$-valeramide, $n$-capronamide, crotonamide, methacrylamide, cyclohexanecarboxamide, benzamide, $o$-aminobenzamide, $m$-aminobenzamide, $p$-aminobenzamide, $p$-toluamide, $p$-chlorobenzamide, p-nitrobenzamide, 2-picolinamide, nicotinamide, pyridine4-carboxamide, pyrazinamide, 2-thiophenecarboxamide, phenylacetamide, indole-3-acetamide, acetonitrile, propionitrile, 3-hydroxypropionitrile, n-capronitrile, methacrylonitrile, crotononitrile, glutaronitrile, 2,4-dicyanobut-1-ene, $\beta$-phenylpropionitrile, cinnamonitrile, 2-cyanopiperidine, 2-cyanopiperazine, phenylacetonitrile, 4-methoxyphenylacetonitrile, $\alpha$-methylbenzyl cyanide, 2-pyridineacetonitrile, 3 -pyridineacetonitrile, thiophene-2-acetonitrile, $\beta$-indoleacetonitrile, diphenylacetonitrile, 4-chlorobenzyl cyanide, benzonitrile, 4-chlorobenzonitrile, 4-nitrobenzonitrile, p-tolunitrile, anisonitrile, 2-cyanophenol, 2-cyanopyridine, 3-cyanopyridine, 4-cyanopyridine, pyrazinecarbonitrile, 3-cyanoindole, $\alpha$-naphtonitrile, 2-thiophenecarbonitrile, terephthalonitrile and isophthalonitrile.

\section{Discussion}

In this paper, we purified an R-amidase from Pseudomonas sp. MCI3434 acting $R$-stereoselectively on $(R, S)$ piperazine-2-tert-butylcarboxamide, cloned its structural gene, $\operatorname{ram} A$, and investigated characteristics of the $\mathrm{R}$-amidase using the recombinant enzyme purified from the $E$. coli transformant.

The amino acid sequence of RamA shared homology with sequences of hypothetical proteins belonging to the carbon-nitrogen hydrolase family from several bacteria and actinomycetes. Pace and Brenner called the carbon-nitrogen hydrolase family the 'nitrilase superfamily'. Based on a comparison of amino acid sequences and biochemical properties, they classified it into 13 branches including nitrilase (branch 1), aliphatic amidase (branch 2), N-terminal amidase (branch 3), biotininase (branch 4), $\beta$-ureidopropionase (branch 5), carbamylase (branch 6), prokaryotic $\mathrm{NAD}^{+}$synthetase (branch 7), eucaryotic NAD ${ }^{+}$synthetase (branch 8), apolipoprotein $N$-acyltransferase (branch 9), Nit and Nitfhit (branch 10), NB11 (branch 11), NB12 (branch 12), and nonfused outliers (branch 13) [39]. Within most branches, there is sharp cut-off in $E$-values obtained with the BLAST program such that sequences with $E$-values greater than $1 \times 10^{-25}$ can be identified as belonging to another branch. Although RamA is most closely related to the $P$. aeruginosa aliphatic amidase among the members of the 13 branches, the level of homology was not so high (26.5\% identity) and the $E$-value was $2 \times 10^{-11}$ between their sequences. This finding suggests that the carbonnitrogen hydrolase family must contain a new branch, into which RamA as well as its homologous sequences, PP3846 from $P$. putida and PA3598 from $P$. aeruginosa, should be classified.

The R-amidase acted on $(R, S)$-piperazine-2-tert-butylcarboxamide with strict $R$-stereoslectivity to form $(R)$-piperazine-2-carboxylic acid. Moreover, R-amidase exhibited significantly unique substrate specificity with hydrolyzing activity only for seven amide compounds listed in Table 3, indicating that the enzyme prefers carboxamide compounds as substrates in which the amino or imino group is connected to $\beta$ - or $\gamma$-carbon of the compounds. The enzyme did not hydrolyze the other amides, peptides, and nitriles. Although RamA shares sequence similarity with $P$. aeruginosa aliphatic amidase as mentioned above, RamA could not hydrolyze aliphatic amides with short acyl chains such as acetamide, propionamide, $n$-butyramide, isobutyramide, and $n$-valeramide which were good substrates for the aliphatic amidase.

As the R-amidase (RamA) has become abundantly available using the DNA technique, E. coli cells producing RamA or a purified recombinant RamA may be of use in the optical resolution of piperazine-2-tert-butylcarboxamide to yield $(R)$-piperazine-2-carboxylic acid and $(S)$-piperazine2-tert-butylcarboxamide. Although $(S)$-piperazine-2-tertbutylcarboxamide, which is an important chiral building block for an HIV protease inhibitor [22], can be prepared by either diastereomeric crystallization using $(S)$-camphorsulfonic acid from its racemic form [40] or asymmetric hydrogenation of tetrahydropyrazine-tert-butylcarboxamide using [( $R)$-BINAP(COD)Rh]TfO catalyst [41], both chemical processes require a harsh reaction condition under high pressure using a much amount of solvents such as acetonitrile, propan-1-ol or methanol. R-Amidase is the first enzyme useful for the enzymatic optical resolution of racemic piperazine-2-tert-butylcarboxamide carried out under mild conditions. 


\section{Acknowledgements}

We thank Dr K. Yazawa (Sagami Chemical Research Center, Kanagawa, Japan) for giving us Pseudomonas sp. MCI3434. We are also grateful to $\mathrm{Dr}$ Y. Kato (Toyama Prefectural University) for determining the $\mathrm{N}$-terminal amino acid sequence and to R. Kasahara and A. Nakayama (Toyama Prefectural University) for their technical assistance. This work was supported by a Grant-in-Aid for Scientific Research (13760076 to H. K.) from JSPS (Japan Society for the Promotion of Science).

\section{References}

1. Ambler, R.P., Auffret, A.D. \& Clarke, P.H. (1987) The amino acid sequence of the aliphatic amidase from Pseudomonas aeruginosa. FEBS Lett. 215, 285-290.

2. Soubrier, F., Lévy-Schil, S., Mayaux, J.-F., Pétré, D., Arnaud, A. $\&$ Crouzet, J. (1992) Cloning and primary structure of the widespectrum amidases from Brevibacterium sp. R312: high homology to the amiE product from Pseudomonas aeruginosa. Gene 116, 99-104.

3. Skouloubris, S., Labigne, A. \& Reuse, H.D. (1997) Identification and characterization of an aliphatic amidases in Helicobacter pylori. Mol. Microbiol. 25, 989-998.

4. Cheong, T.K. \& Oriel, P.J. (2000) Cloning of a wide-spectrum amidase from Bacillus stearothermophilus BR388 in Escherichia coli and marked enhancement of amidase expression using directed evolution. Enzyme Microb. Technol. 26, 152-158.

5. Scorpio, A. \& Zhang, Y. (1996) Mutations in pncA, a gene encoding pyrazinamidase/nicotinamidase, cause resistance to the antituberculous drug pyrazinamide in tubercle bacillus. Nat. Med. 2, 662-667.

6. Asano, Y. \& Lübbehüsen, T.L. (2000) Enzymes acting on peptides containing D-amino acid. J. Biosci. Bioeng. 89, 295-306.

7. Kamphuis, J., Boesten, W.H.J., Broxterman, Q.B., Hermes, H.F.M., van Balken, J.A.M., Meijer, E.M. \& Schoemaker, H.E. (1990) New developments in the chemoenzymatic production of amino acids. Adv. Biochem. Eng. Biotechnol. 42, 133-186.

8. Schmid, A., Dordick, J.S., Hauer, B., Kiener, A., Wubbolts, M. \& Witholt, B. (2001) Industrial biocatalysis today and tomorrow. Nature 409, 258-268.

9. Mayaux, J.-F., Cerbelaud, E., Soubrier, F., Faucher, D. \& Pétré, D. (1990) Purification, cloning, and primary structure of an enantiomer-selective amidases from Brevibacterium sp. strain R312: structural evidence for genetic coupling with nitrile hydratase. J. Bacteriol. 172, 6764-6773.

10. Ciskanik, L.M., Wilczek, J.M. \& Fallon, R.D. (1995) Purification and characterization of an enantioselective amidases from $P$ seudomonas chlororaphis B23. Appl. Environ. Microbiol. 61, 998-1003.

11. Kobayashi, M., Komeda, H., Nagasawa, T., Nishiyama, M., Horinouchi, S., Beppu, T., Yamada, H. \& Shimizu, S. (1993) Amidase coupled with low-molecular-mass nitrile hydratase from Rhodococcus rhodochrous $\mathrm{J} 1$ : sequencing and expression of the gene and purification and characterization of the gene product. Eur. J. Biochem. 217, 327-336.

12. Trott, S., Bauer, R., Knackmuss, H.-J. \& Stolz, A. (2001) Genetic and biochemical characterization of an enantioselective amidase from Agrobacterium tumefciens strain d3. Microbiology 147, 18151824.

13. Hayashi, T., Yamamoto, K., Matsuo, A., Otsubo, K., Muramatsu, S., Matsuda, A. \& Komatsu, K. (1997) Characterization and cloning of an enantioselective amidase from Comamonas acidovorans KPO-2771-4. J. Ferment. Bioeng. 83, 139-145.

14. Hermes, H.F.M., Sonke, T., Peters, P.J.H., van Balken, J.A.M., Kamphuis, J., Dijkhuizen, L. \& Meijer, E.M. (1993) Purification and characterization of an 1-aminopeptidase from Pseudomonas putida ATCC 12633. Appl. Environ. Microbiol. 59, 4330-4334.

15. van den Tweel, W.J.J., van Dooren, T.J.G.M., de Jonge, P.H., Kaptein, B., Duchateau, A.L.L. \& Kamphuis, J. (1993) Ochrobactrum anthropi NCIMB 40321: a new biocatalyst with broadspectrum 1-specific amidases activity. Appl. Microbiol. Biotechnol. 39, 296-300.

16. Hermes, H.F.M., Tandler, R.F., Sonke, T., Dijkhuizen, L. \& Meijer, E.M. (1994) Purification and characterization of an 1-amino amidase from Mycobacterium neoaurum ATCC 25795. Appl. Environ. Microbiol. 60, 153-159.

17. Komeda, H. \& Asano, Y. (2000) Gene cloning, nucleotide sequencing, and purification and characterization of the D-stereospecific amino-acid amidase from Ochrobactrum anthropi SV3. Eur. J. Biochem. 267, 2028-2035.

18. Ozaki, A., Kawasaki, H.M., Yagasaki, M. \& Hashimoto, Y. (1992) Enzymatic production of D-alanine from DL-alaninamide by novel D-alaninamide specific amide hydrolase. Biosci. Biotechn Biochem. 56, 1980-1984.

19. Baek, D.H., Kwon, S.-J., Hong, S.-P., Kwak, M.-S., Lee, M.-H., Song, J.J., Lee, S.-G., Yoon, K.-H. \& Sung, M.-H. (2003) Characterization of a thermostable D-stereospecific alanine amidase from Brevibacillus borstelensis BCS-1. Appl. Environ. Microbiol. 69, 980-986.

20. Bigge, C.F., Johnson, G., Ortwine, D.F., Drummond, J.T., Retz, D.M., Brahce, L.J., Coughenour, L.L., Marcoux, F.W. \& Probert, A.W. (1992) Exploration of $N$-phosphonoalkyl-, $N$-phosphonoalkenyl-, and $N$-(phosphonoalkyl) phenyl-spaced alpha-amino acids as competitive $N$-methyl-D-aspartic acid antagonists. J. Med. Chem. 35, 1371-1384.

21. Bruce, M.A., Laurent, D.R.S., Poindexter, G.S., Monkovic, I., Huang, S. \& Balasubramanian, N. (1995) Kinetic resolution of piperazine-2-carboxamide by leucine aminopeptidase: an application in the synthesis of the nucleoside transport blocker (-)draflazine. Synthetic Commun. 25, 2673-2684.

22. Askin, D., Eng, K.K., Rossen, K., Purick, R.M., Wells, K.M., Volante, R.P. \& Reider, P.J. (1994) Highly diastereoselective reaction of a chiral, non-racemic amide enolate with $(S)$-glycidyl tosylate: synthesis of the orally active HIV-1 protease inhibitor L-735,524. Tetrahedron Lett. 35, 673-676.

23. Eichhorn, E., Roduit, J.-P., Shaw, N., Heinzmann, K. \& Kiener, A. (1997) Preparation of (S)-piperazine-2-carboxylic acid, $(R)$-piperazine-2-carboxylic acid, and $(S)$-piperizine-2-carboxylic acid by kinetic resolution of the corresponding racemic carboxamides with stereoselective amidases in whole bacterial cells. Tetrahed. Asymm. 8, 2533-2536.

24. Sambrook, J., Fritsch, E.F. \& Maniatis, T. (1989) Molecular Cloning: a Laboratory Manual, 2nd edn. Cold Spring Harbor Laboratory, Cold Spring Harbor N.Y.

25. Misawa, N., Nakagawa, M., Kobayashi, K., Yamano, S., Izawa, Y., Nakamura, K. \& Harashima, K. (1990) Elucidation of the Erwinia uredovora carotenoid biosynthetic pathway by functional analysis of gene products expressed in Escherichia coli. J. Bacteriol. 172, 6704-6712.

26. Inoue, H., Nojima, H. \& Okayama, H. (1990) High efficiency transformation of Escherichia coli with plasmids. Gene 96, 23-28.

27. Sanger, F., Nicklen, S. \& Coulson, A.R. (1977) DNA sequencing with chain-terminating inhibitors. Proc. Natl Acad. Sci. USA 74, 5463-5467.

28. Altschul, S.F., Gish, W., Miller, W., Myers, E.W. \& Lipman, D.L. (1990) Basic local alignment search tool. J. Mol. Biol. 215, 403-410.

29. Bradford, M.M. (1976) A rapid and sensitive method for the quantitation of microgram quantities of protein utilizing the principle of protein-dye binding. Anal. Biochem. 72, 248-254. 
30. Fawcett, J.K. \& Scott, J.E. (1960) A rapid and precise method for the determination of urea. J. Clin. Pathol. 13, 156-159.

31. Conway, E.J. \& Byrne, A. (1933) An absorption apparatus for the microdetermination of certain volatile substances. I. The microdetermination of ammonia. Biochem. J. 27, 419-429.

32. Laemmli, U.K. (1970) Cleavage of structural proteins during the assembly of the head of bacteriophage T4. Nature 227, 680-685.

33. Stover, C.K., Pham, X.Q., Erwin, A.L., Mizoguchi, S.D., Warrener, P., Hickey, M.J., Brinkman, F.S., Hufnagle, W.O., Kowalik, D.J., Lagrou, M., Garber, R.L., Goltry, L., Tolentino, E., Westbrock-Wadman, S., Yuan, Y., Brody, L.L., Coulter, S.N., Folger, K.R., Kas, A., Larbig, K., Lim, R., Smith, K., Spencer, D., Wong, G.K., Wu, Z., Paulsen, I.T., Reizer, J., Saier, M.H., Hancock, R.E., Lory, S. \& Olson, M.V. (2000) Complete genome sequence of Pseudomonas aeruginosa PA01, an opportunistic pathogen. Nature 406, 959-964.

34. Bentley, S.D., Chater, K.F., Cerdeno-Tarraga, A.M., Challis, G.L., Thomson, N.R., James, K.D., Harris, D.E., Quail, M.A., Kieser, H., Harper, D., Bateman, A., Brown, S., Chandra, G., Chen, C.W., Collins, M., Cronin, A., Fraser, A., Goble, A., Hidalgo, J., Hornsby, T., Howarth, S., Huang, C.H., Kieser, T., Larke, L., Murphy, L., Oliver, K., O’Neil, S., Rabbinowitsch, E., Rajandream, M.A., Rutherford, K., Rutter, S., Seeger, K., Saunders, D., Sharp, S., Squares, R., Squares, S., Taylor, K., Warren, T., Wietzorrek, A., Woodward, J., Barrell, B.G., Parkhill, J. \& Hopwood, D.A. (2002) Complete genome sequence of the model actinomycete Streptomyces coelicolor A3(2). Nature 417, 141-147.

35. Schnider, U., Keel, C., Defago, G. \& Haas, D. (1995) Tn5 directed cloning of $p q q$ genes from Pseudomonas fluorescens CHA0: mutational inactivation of the genes results in overproduction of the antibiotic pyoluteorin. Appl. Environ. Microbiol. 61, 38563864.

36. Nelson, K.E., Weinel, C., Paulsen, I.T., Dodson, R.J., Hilbert, H., Martins dos Santos, V.A.P., Fouts, D.E., Gill, S.R., Pop, M.,
Holmes, M., Brinkac, L., Beanan, M., DeBoy, R.T., Daugherty, S., Kolonay, J., Madupu, R., Nelson, W., White, O., Peterson, J., Khouri, H., Hance, I., Chris Lee, P., Holtzapple, E., Scanlan, D., Tran, K., Moazzez, A., Utterback, T., Rizzo, M., Lee, K., Kosack, D., Moestl, D., Wedler, H., Lauber, J., Stjepandic, D., Hoheisel, J., Straetz, M., Heim, S., Kiewitz, C., Eisen, J., Timmis, K.N., Duesterhoeft, A., Tuemmler, B. \& Fraser, C.M. (2002) Complete genome sequence and comparative analysis of the metabolically versatile Pseudomonas putida KT2440. Environ. Microbiol. 4, 799-808.

37. Capela, D., Barloy-Hubler, F., Gouzy, J., Bothe, G., Ampe, F., Batut, J., Boistard, P., Becker, A., Boutry, M., Cadieu, E., Dreano, S., Gloux, S., Godrie, T., Goffeau, A., Kahn, D., Kiss, E., Lelaure, V., Masuy, D., Pohl, T., Portetelle, D., Puhler, A., Purnelle, B., Ramsperger, U., Renard, C., Thebault, P., Vandenbol, M., Weidner, S. \& Galibert, F. (2001) Analysis of the chromosome sequence of the legume symbiont Sinorhizobium meliloti strain 1021. Proc. Natl Acad. Sci. USA 98, 9877-9882.

38. Ikeda, H., Ishikawa, J., Hanamoto, A., Shinose, M., Kikuchi, H., Shiba, T., Sakaki, Y., Hattori, M. \& Omura, S. (2003) Complete genome sequence and comparative analysis of the industrial microorganism Streptomyces avermitilis. Nat. Biotechnol. 21, 526531.

39. Pace, H.C. \& Brenner, C. (2001) The nitrilase superfamily: classification, structure and function. Genome Biol. 2, 1-9.

40. Askin, D., Eng, K.K., Reider, P. \& Volante, R.P. (1996) Process to make HIV protease inhibitor from 2-(S)-4-picolyl-2-piperazine- $t$ butylcarboxamide. PCT/US96/02556.

41. Rosen, K., Weissman, S.A., Sager, J., Reamer, R.A., Askin, D., Volante, R.P. \& Reider, P.J. (1995) Asymmetric hydrogenation of tetrahydropyrazines: synthesis of $(S)$-piperazine-2-tert-butylcarboxamide, an intermediate in the preparation of the HIV protease inhibitor indinavir. Tetrahedron Lett. 36, 6419-6422. 